\title{
Community-Based Approach in Developing Farm Tourism
}

\author{
Nerisa Paladan \\ Agribusiness Department, Partido State University, Goa, Philippines \\ Email:npaladan@gmail.com
}

How to cite this paper: Paladan, N. (2020) Community-Based Approach in Developing Farm Tourism. Open Access Library Journal, 7: e7043.

https://doi.org/10.4236/oalib.1107043

Received: November 26, 2020

Accepted: December 25, 2020

Published: December 28, 2020

Copyright (C) 2020 by author(s) and Open Access Library Inc.

This work is licensed under the Creative Commons Attribution International License (CC BY 4.0).

http://creativecommons.org/licenses/by/4.0/

http://creativecommons.org/lice

\begin{abstract}
The sustainability of agriculture and tourism are always challenged and their impact on rural development. The called for community-based approach is needed to make agriculture and tourism sustainable and thriving. The study aims to develop farm tourism through community-based approach towards sustainability of agriculture and its rural development. Specifically, it considered the steps in developing community-based farm tourism in two selected communities, evaluates its feasibility, documented its benefits and challenges, and determined the lesson learned from its process. It uses qualitative research design where it highlights and documents the process of establishing farm tourism through community-based approach and its feasibility. Two selected communities are the respondent of this study. Survey-interview and focus group discussion was utilized. Focus group discussion in the two communities was used during the orientation and process of establishing farm tourism. Findings reveal that establishing farm tourism through community-based approach requires preliminary actions before its actual process. There are four steps to start and develop community-based tourism initiatives such as community assessment; educate and prepare the community for tourism; identify and establish leadership team/local champion; and plan and design quality products. It was reflected that the main benefit of developing community-based farm tourism is the livelihood it offers and this is also the main reason why they join this project. Establishing farm tourism through community-based approach is a process; it needs a support system; takes time to thrive; and it needs a different approach to sustain the project.
\end{abstract}

\section{Subject Areas \\ Tourism, Agribusiness}

\section{Keywords}

Farm Tourism, Community-Based Tourism, Women's Farmer's Communities 


\section{Introduction}

In recent years, most of the countries have focused their attention on sustainability of agriculture and that is also one of the concerns in the Philippines. It needs full support for biodiversity and environment system of farming practices that contributes to a sustainable agriculture and provides a doable prospect for all stakeholders (Colliver et al., 2010) [1]. Agritourism is recognized as an essential strategy that can add to agricultural development through diversification of farming activities and offering opportunities to rest, relax, enjoy and study about farming for the visitors. There is a growing attention for agritourism in the academic literature since it was been extensively promoted both in developed and developing countries like Philippines. Likewise, agro-tourism contributes a significant improvement to the economic life of the local communities.

Farm tourism was created out of a realistic substitute to be self-employed instead of looking off-farm employment (Brandth and Haugen, 2010) [2]. It can create job opportunities for young family members, reducing the need to work out of farms. In this way, the young population can be kept in rural areas (Barbieri, 2009) [3]. It offers income diversification and social goals which rural families have a practice of hospitality, in spite of income concern (Canoves et al., 2004; Hall and Rusher 2004) [4] [5]. Farm tourism has several benefits in terms of economic, environmental and socio-cultural and as a development strategy for rural areas and the value of agricultural tourism/farm tourism has been growing day by day.

The multifaceted combinations of economic and non-economic objectives generate a dynamic force in the diversification of farm operation and in particular in the development of farm tourism (Barbieri, 2010) [6]. It can be shown in different ways and studies the aspiration of the development of farm tourism (Barbieri, 2009; 2010; Ollenburg ve Buckley, 2007) [3] [6] [7]. And the benefits of farm tourism are grouped into economic and non-economic benefits (Tew ve Barbieri, 2012: 215; Nickerson vd., 2001) [8] [9]. Likewise, the diversification of the farms used for agriculture is a view as a preferred strategy to preserve the way of life of the farmers and to deal with the varying agricultural climate (Barbieri ve Mahoney, 2009) [10].

Farms working on farm tourism utilize more sustainable techniques on biodiversity, environment and natural resources, which produce an effect of decreasing the harmful impact of agriculture on the environment (Mastronardi et al., 2015) [11]. Most of the farm tourism is owned and manage by private individual and one of strategy to promote and develop farm tourism is through community-based approach.

According to Goodwin and Santilli (2009) [12], community-based tourism (CBT) can be described as tourism owned and managed by community and planned to deliver wider community benefits. In a CBT local participation and managing over the control of the community is one of the features that will result in a more livelihood benefit (Reid, 2003) [13]. However, CBT needs to be 
approached in a logical manner. This necessitate a study of the appropriateness of the community to be involved in tourism to pledge that community members are provided the opportunity to partake in related projects and are concerned in monitoring and controlling the negative impacts (Kiss, 2004) [14].

In the Asia Pacific Economic Cooperation (APEC) Forum's Tourism Charter it emphasizes the community-based tourim (CBT) that was endorsed at the first Tourism Ministerial Meeting held in Korea in 2000 (APEC, 2014) [15]. Several CBT projects in the Asia Pacific region can be found in the literature, however, it's a mostly one-off project that is often initiated and operated by non-governmental organizations (NGOs) (Ashley and Garland, 1994) [16].

APEC (2014) [15] state that CBT offers a high likelihood to generate jobs, and create entrepreneurial opportunities for local communities coming from a difference of backgrounds, skills, and experiences, also as a poverty reduction tool too. In addition, CBT is recognized as a broad-based plan that enhances the rural and urban economies. It also creates opportunities for the betterment of the community's livelihood. It is also considered the community development tool that strengthens the ability of rural communities to manage tourism resources while ensuring the local community's participation (GetzD, 1995) [17]. A long-term approach is needed for $\mathrm{CBT}$ and must take advantage of the benefits for the local community and not dwell on the negative impacts of tourism to the community and to their environmental resources. While CBT idea mature, the adoption of a holistic business model is crucial in weaning the project from government or donor reliance, as well as to scale up the project (Mitchell and Reid, 2001; Reed, 1997) [18] [19].

Also, Ljunggren ve Petterson (2003) [20], state that the farmers' decisions to open their farms to tourists, was considered as an interventional movement, there is no clarity about the force that drove them such an initiative. Farm tourism and community-based tourism offer almost the same benefits to the local community and rural development. Integrating them would be a great help to the farmers and sustainability of agriculture. However, most of the local communities are not knowledgeable concerning CBT. Due to the lack of knowledge and resources local community is not always working together as one group (Tosun, 2000) [21] and this is one of the challenges in community-based farm tourism. Another is communities in third world countries are the most unaware of the costs and difficulties associated with rapid development of tourism in their community (Rosenow and Pulsipher, 1979) [22].

With this situation it necessitates a study in helping the farmer's community how to establish community-based farm tourism. This study aims to develop farm tourism through community-based approach towards sustainability of agriculture and agribusiness activities and its rural development. Specifically, it aims to document how to establish farm tourism using community-based approach, assess its benefits and challenges, the market feasibility and identify the lesson learned in establishing farm tourism using community-based approach. 
Although, community involvement view as panacea there are still some people who are not joining tourism activities because of the unknown reason (Tosun, 2000) [21]. The primary stakeholders in a tourism development are the local communities. However, the attitude of the local communities can affect the development of tourism industry particularly in a CBT project if the participation of the local community is not satisfying. Therefore, there is a need for a thorough study in organizing community for farm tourism and let them involved in the process so that they could own their community-based farm tourism.

\section{Materials and Methods}

The study utilized of descriptive research design. Descriptive design was used in this study since it does not prove any theory but highlight the process how to start and develop community-based farm tourism and its feasibility. The study was carried out in San Jose, Camarines Sur particularly in the two barangays the Calalahan and Tagas. The study area was considered due to the reason that the local government unit prioritizes the promotion of their tourism and there is a potential for developing farm tourism through community-based approach in this area.

The main respondents of the study are the women farmers' community of Calalahan and Tagas, San Jose, Camarines Sur that has a potential for forming farmer's communities for farm tourism. Consent of the women's farmers of Calalahan and Tagas was secure before the project started and since joining in this project is on a voluntary basis and the data that will be provided by the respondents will be used for study proposes only. Also, key informant from the local communities and tourism office and department of agriculture of San Jose, Camariness was included as respondent of this study.

The study utilized both primary and secondary data. Primary data coming directly from the women farmer's communities their participation and cooperation in forming farmer's community for farm tourism and the data that was provided by the key informant of the tourism office and department of agriculture of San Jose, Camarines Sur. Interview and focus group discussion was used to gathered data. The interview method presents thorough answers and gives respondent's autonomy of self-expression (Healey, 2009) [23]. While the focus group discussion method is intended to be more flexible and therefore helps to investigate in-depth information about the group's attitudes, perceptions and experiences on a defined topic (Vaske, 2008) [24]. There were three focus group discussions that were conducted and it were participated by the members. The topic that was discussed during the focus group discussions are the following: assessment and motivation in joining the project, the need for organization and re-organization of the community, and product and enterprise development.

The result was compared with other reviewed literature which was link with the study theme. Daly et al. (2007) [25] state that conclusions for a new knowledge can be reached in a research study if there is reliability in the knowledge 
base and the theory. The result from the study areas was comprehensive to explain the situation of establishing farm tourism through community-based approach.

\section{Results and Discussion}

\subsection{Establishing Farm Tourism using Community-Based Approach}

Community-based tourism is gradually more popular as a pro-poor expansion development tool. Ahead of the common style, several host of community-based tourism now exists in the Asia Pacific region just like the Philippines. In the study of successful community-based tourism approaches to rural development of Vikneswaran Nair and Amran Hamzah (2015) [26], it state that there are four steps to start and develop community-based tourism initiatives. First, assess community needs and readiness for tourism. Second, educate and prepare the community for tourism. Third, identify and establish leadership team/local champion. Lastly, plan and design quality products. This step was adopted in this study in developing farm tourism using community-based approach. Although there are some modifications in the process of establishing farm tourism in this two selected barangays of San Jose, Camarines Sur. The modification depends on the unique situation of each location.

In establishing farm tourism in Calalahan and Tagas, San Jose, Camarines Sur, there were preliminary actions before the first step were implemented. The preliminary action includes coordination with the barangay local government unit (BLGU), getting their support and commitment for the project and forming community for the farm tourism project. Coordination to the two barangay local government units was conducted by requesting a meeting to the barangay captain and informs them about the farm tourism project and gets their approval to implement the said project in their barangay. Both the two barangays local government unit where interested and give their support to the project. Also, both the two barangays local government unit provided the venue for the meetings and trainings for the said project as their support. The barangay captain of Calalahan and Tagas is also present from time to time to show their commitment for the project. Since this project is a community-based approach in developing farm tourism it needs an organization/community for the project. In Calalahan it needs to organize a community for this project and it was suggested by the barangay captain to form the women farmers' community who will be part of the project. While in Tagas, they already have a women's organization but need to reorganize as requested by the existing president of the organization.

In organizing women's farmer community both started with mapping and profiling of those women farmers in terms of their age, civil status and educational background who are interested to join the organization and in the project. In Table 1 reflected the profile of women's organization of Calalahan and Tagas women organization. 
Table 1. Profile of the respondent.

\begin{tabular}{|c|c|c|c|c|c|}
\hline Personal Characteristic & $\mathbf{N}$ & $\%$ & Personal Characteristic & $\mathbf{N}$ & $\%$ \\
\hline \multicolumn{3}{|c|}{ Calalahan Women's Organization } & \multicolumn{3}{|c|}{ Tagas Women's Organization } \\
\hline Age & & & Age & & \\
\hline 51 to 60 & 6 & 30 & 61 and up & 6 & 24 \\
\hline 41 to 50 & 9 & 45 & 51 to 60 & 9 & 36 \\
\hline 31 to 40 & 3 & 15 & 41 to 50 & 7 & 28 \\
\hline 21 to 30 & 2 & 10 & 31 to 40 & 2 & 8 \\
\hline \multirow[t]{2}{*}{ Total } & 20 & 100 & 21 to 30 & 1 & 4 \\
\hline & & & Total & 25 & 100 \\
\hline Civil Status & & & Civil Status & & \\
\hline Married & 14 & 70 & Married & 19 & 76 \\
\hline Widow & 4 & 20 & Widow & 3 & 12 \\
\hline Did not Answer & 2 & 10 & Single & 1 & 4 \\
\hline \multirow[t]{3}{*}{ Total } & 20 & 100 & Others & 1 & 4 \\
\hline & & & Did not Answer & 1 & 4 \\
\hline & & & Total & 25 & 100 \\
\hline Educational Background & & & Educational Background & & \\
\hline Collge Grad & 1 & 5 & Collge Grad & 3 & 12 \\
\hline Collge Level & 3 & 15 & Collge Level & 3 & 12 \\
\hline HS Grad & 6 & 30 & HS Grad & 5 & 20 \\
\hline HS Level & 3 & 15 & HS Level & 4 & 16 \\
\hline Elem Grad & 7 & 35 & Elem Grad & 8 & 32 \\
\hline \multirow[t]{3}{*}{ Total } & 20 & 100 & Vocational & 1 & 4 \\
\hline & & & Did not Answer & 1 & 4 \\
\hline & & & Total & 25 & 100 \\
\hline
\end{tabular}

The profiles of Calalahan women's organization as shown in Table 1, in term of age $45 \%$ or majority are between 41 to 50 years old, followed by 51 to 60 years old which is $30 \%$ and there are some between 31 to 40 and 21 to 30 years old. In terms of civil status $70 \%$ or majority of the members are married and some are already widow. For their educational background majority or 35\% are elementary school graduate, followed by high school graduate which is $30 \%$. There are some who reach college level and college graduate.

In Table 1, also reflects the profile of Tagas women's association, in terms of age $36 \%$ or majority are between 41 to 50 years old, followed by 51 to 60 years old which is $28 \%$, and there is $24 \%$ for 61 year old and above. In terms of civil status, $76 \%$ or majority are married, $12 \%$ widow and there are some who are single. For their educational background, $32 \%$ or majority is elementary graduate, followed by $20 \%$ high school graduate and there are some who reach college level and graduated.

These indicate that the members of Calalahan women's organization and Ta- 
gas women association are now in their forties and married where they look for additional income for their family despite their limitation in terms of their educational background. They are willing to join and be part of the organization or association to help each other to have additional livelihood.

Applying the first step to start and develop community-based tourism initiatives which is the assessment of community needs and readiness for tourism. The essential question that needs to consider for the $1^{\text {st }}$ step was why Calalahan and Tagas Women's community should be involved in tourism?

In Table 2 reflects the answers to the question and the response of the members of Calalahan and Tagas Women's community was 55\% and $64 \%$ respectively, they want to learn new skills and additional knowledge. Also $15 \%$ and $24 \%$ of Calalahan and Tagas womens community mention that they want to have alternative livelihood. Although both Calalahan and Tagas Women's Community have a minimal understanding of what is community-based farm tourism and how it works.

Both barangay Calalahan and Tagas had initial activity for tourism, in Calalahan there is a flower farm and a mushroom production both are manage by a private individual while in Tagas they have the Ecopark Resort. However, in Tagas the Ecopark is managed by the Tagas women's community in collaboration with the barangay local government and the municipal local government of San Jose, Camarines Sur.

The role of tourism in Calalahan and Tagas offer variety of opportunities such as livelihood for the women's community and job creation. This is similar to the study of Anuar and Sood (2017) [27], it state that community-based tourism offers a great opportunity to create jobs, and form entrepreneurial prospects for local communities from a difference of backgrounds, skills, and experiences.

The second step to start and develop community-based tourism initiatives is to educate and prepare the community for tourism. When community decides to engage in tourism, preparing and educating them are essential as documented in Kaikura, New Zealand; Ta Phin, Vietnam; Guisi, Guimaras, Philippines; and in Misowalai (Whale Watch Kaikoura, 2014; Gill, 2009; CBT Vietnam, 2014; Footprint Travel Guides, 2014; Footprint Vietnam Travel, 2014; Son, 2009; Province of Guimaras, 2009; Angeles Gabinete, 2009; and KOPEL, 2014; Hamid, 2009) respectively.

Table 2. Respondent reasons for joining the project.

\begin{tabular}{ccccc}
\hline \multirow{2}{*}{ Reasons for Joining the Project } & \multicolumn{2}{c}{ Tagas } & \multicolumn{2}{c}{ Calalahan } \\
\cline { 2 - 5 } & $\mathbf{N}$ & $\%$ & $\mathbf{N}$ & $\%$ \\
\hline Learn new skills and additional knowledge & 16 & 64 & 11 & 55 \\
Employment and additional income & 6 & 24 & 3 & 15 \\
Help \& share my services & 3 & 12 & 3 & 15 \\
Did not answer & & & 3 & 15 \\
Total & 25 & 100 & 20 & 100 \\
\hline
\end{tabular}


Preparing and educating communities for farm tourism involves conduct of preliminary workshop; study trip and "community to community" training; and formulation of training manual (Vikneswaran Nair and Amran Hamzah, 2015) [26]. For this study it only conducted some preliminary workshop like orientation about community-based farm tourism. However, because of the limited time other workshop to deepen their knowledge about community-based farm tourism was not yet implemented and also the study trip and "community to community" training. Another reason that was mention by Calalahan and Tagas community is for them to develop the leadership of the community and having a product or enterprise is more urgent. Nevertheless, these steps will still be considered as the project progress.

The third step to start and develop community-based tourism initiatives is to identify and establish leadership team/local champion (Vikneswaran Nair and Amran Hamzah, 2015) [26]. It was observed that both the community of Calalahan and Tagas women association sees the urge to identify and established their leadership team. For Calalahan, since they are just starting their organization identifying and establishing their leadership team is essential for them. This will help their organization to have direction and someone to lead them. While for Tagas, it was noticed that the association call for re-establishment of the leadership of their organization. Since their previous leadership team becomes inactive and some have other concerns. They believe that it's time to change the leadership team for the improvement of their organization. Leadership team in a community-based tourism plays a vital role in the success of the project.

The last step to start and develop community-based tourism initiatives is to plan and design quality products (Vikneswaran Nair and Amran Hamzah, 2015) [26]. It was observed that in establishing community-based farm tourism one of the elements is to produce quality products that can distinguish their community farm. The department of trade and industry suggested that they could start from the indigenous materials in their area. Like for Calalahan women's association in their area they have huge supply of bamboo so they are planning to engage in bamboo winnowing product and for Tagas women's association they plan to engage in producing decorative hat. This is an added feature of their community-based farm tourism.

\subsection{Benefits and Challenges in Developing a Community-Based Farm Tourism}

Developing community-based farm tourism that will be owned and managed by a community can provide broader community benefits (Goodwin and Santilli, 2009) [12]. This is also one of the tourism components that offer a lot of benefits for local community (Anuar \& Sood, 2017) [27]. Supported by the study of Mitchel RE, Reid DG (2001) [18] where it mention that since community-based farm tourism is a local participation, and giving them the control to the community there is more possibility of livelihood outcomes. Therefore the main benefit of developing community-based farm tourism is the livelihood it offers 
that most of the members of the community are after and this is also their main reason why they join this project. According to Anuar \& Sood (2017) [27], community-based tourism offers a high opportunity to create jobs, and generate entrepreneurial chances for local communities from a different of backgrounds, skills, and experiences. Another benefit of community-based tourism it acts as a tool to strengthen the capability of the rural communities to manage tourism resources though making sure that the local community will participate (Jamal TB, Getz D, 1995) [17]. To sum-up the benefits in developing community-based farm tourism, according to Asia Pacific Economic Cooperative (APEC 2000) [28], community-based tourism support the local community in creating income, diversifying the local economy, conserving culture, preserving the environment, and providing educational opportunities.

With the benefits of developing community-based farm tourism several developing countries use this as a tool to improve the quality of life and also to support their economic level. However, developing community-based farm tourism has also challenges. One of the challenges of community-based tourism is the local community's attitude towards participation for the project. At start they are hesitant to partake and they are also impatience if it does not give them the results that they want immediately. This was highlighted in the study of Sebele (2010) [29] pointed out that some community members feel that the cost they must incur by participating in CBT is far outweighed the benefits.

Other challenges that was identify are the following: the conditions of the farmers, farmers ignorance, misconception of community-based farm tourism, family farms preservation, unorganized sector of Farm tourism industry, issues on hygiene and basic requirements considering tourist or foreign visitors, declining number of farmers, and the growing number of week agriculture crop due to the uncertain climatic conditions.

Nevertheless developing community-based farm tourism is a process that will take time to progress. Study of Anuar \& Sood (2017) [27] stated that the local community's attitude can affect the development of tourism industry particularly in community-based tourism project if the local community participation is not satisfying. Even though community involvement can be consider as a solution there are still some people who are not joining tourism activities because of unknown reason (Tosun, 2000) [21].

Therefore, for community-based tourism to be effective it requires extensive community participation and involvement in assessment, planning and as well as in the implementation. This will give them high potential to empower local community's members to develop skills, knowledge, and confidence that needed to direct tourism development in their communities.

\subsection{Market Feasibility of Establishing Farm Tourism Using Community-Based Approach}

In establishing community-based farm tourism it is essential to assess the market feasibility. Market feasibility is being conducted to determine if there is a 
market for this type of tourism. In evaluating the market feasibility of establishing community-based farm tourism for this study it considered three important things: first, the demand for the services. Second, the features of community based farm tourism and third, the marketing strategy to market this type of tourism.

As shown in Table 3, Bicol is included in the top three visited by tourist last 2018. So among the regions in the Philippines, Bicol is one of the regions where huge fluxes of tourist are coming every year. While in Table 4 reflects that among the provinces in Bicol region, Camarines Sur has the highest tourist arrival last 2018. It indicates that the tourism industry in the Bicol region is growing and progressive particularly Camarines Sur as reflected in Table 5. In the last five years from 2014 to 2018 the tourist arrival in Camarines Sur is increasing from $111 \%$ up to $166 \%$. With the increasing tourist arrival it has a great potential to integrate community-based farm tourist in the tour packages. Community-based farm tourism can take advantage of this opportunity to increase awareness of the tourist about farm tourism. They can collaborate with tour operator, used flyers and social media to promote community-based farm tourism and can make used of story how their community was form for this project. That when they patronage the service in the community-based farm tourism they directly help the local communities particularly the women's farmer and the sustainability of agriculture.

There is a growing tourism industry in Bicol region as reflected in Table 5 and Camarines Sur is one of the places the tourist would usually visit because of its fascinating beaches such as Caramoan Island. Since, there is a huge influx of tourist to Caramoan Island this could be the target market for this community-based farm tourism. Tour packages for Caramoan Island can include visiting this community-based farm tourism.

In promoting the community-based farm tourism, this project utilized both social media like facebook and tarpaulin where it reflected the features of the farm tourism in Calalahan and Tagas as presented in Figure 1 and Figure 2.

Table 3. Top 5 region visited by tourist 2018 .

\begin{tabular}{cccccc}
\hline Region & $\begin{array}{c}\text { Foreign } \\
\text { Traveler }\end{array}$ & $\begin{array}{c}\text { Overseas } \\
\text { Traveler }\end{array}$ & $\begin{array}{c}\text { Domestic } \\
\text { Traveler }\end{array}$ & $\begin{array}{c}\text { Total } \\
\text { Traveler }\end{array}$ & Rank \\
\hline $\begin{array}{c}\text { Region III } \\
\text { CENTRAL LUZON) }\end{array}$ & 339,910 & 6977 & $4,139,477$ & $4,486,364$ & 5 \\
$\begin{array}{c}\text { Region IV-A } \\
\text { CALABARZON }\end{array}$ & 564,121 & 3532 & $7,051,421$ & $7,619,074$ & 2 \\
$\begin{array}{c}\text { Region V } \\
\text { (BICOL REGION) }\end{array}$ & $1,003,485$ & 22,674 & $5,091,441$ & $6,117,600$ & 3 \\
$\begin{array}{c}\text { Region VI } \\
\text { (WESTERN VISAYAS) }\end{array}$ & 783,731 & 43,095 & $4,129,072$ & $4,955,898$ & 4 \\
$\begin{array}{c}\text { Region VII } \\
\text { (CENTRAL VISAYAS) }\end{array}$ & $3,602,646$ & 31,649 & $4,465,051$ & $8,099,346$ & 1 \\
\hline
\end{tabular}

Source: https://psa.gov.ph/. 
Table 4. Tourist Arrival in Bicol for 2018.

\begin{tabular}{cccccc}
\hline Provinces & $\begin{array}{c}\text { Foreign } \\
\text { Traveler }\end{array}$ & $\begin{array}{c}\text { Overseas } \\
\text { Traveler }\end{array}$ & $\begin{array}{c}\text { Domestic } \\
\text { Traveler }\end{array}$ & $\begin{array}{c}\text { Total } \\
\text { Traveler }\end{array}$ & Rank \\
\hline Albay & 395,225 & 205 & $1,434,338$ & $1,829,768$ & 2 \\
Camarines Norte & 41,466 & 21,066 & 499,113 & 561,645 & 3 \\
Camarines Sur & 514,913 & & $2,568,371$ & $3,083,284$ & 1 \\
Catanduanes & 7,759 & & 221,463 & 229,222 & 4 \\
Masbate Province & 8425 & 6 & 151,072 & 159,503 & 5 \\
Sorsogon Province & 35,697 & 1397 & 217,084 & 254,178 & 3 \\
\hline
\end{tabular}

Source: https://psa.gov.ph/.

Table 5. Tourist arrival in bicol region and camarines sur for the last 5 years.

\begin{tabular}{cccccc}
\hline Region & $\mathbf{2 0 1 4}$ & $\mathbf{2 0 1 5}$ & $\mathbf{2 0 1 6}$ & $\mathbf{2 0 1 7}$ & $\mathbf{2 0 1 8}$ \\
\hline Region V (BICOL REGION) & $3,724,073$ & $4,526,007$ & $5,409,342$ & $6,039,897$ & $6,117,600$ \\
Increase in the tourist arrival & $100 \%$ & $122 \%$ & $145 \%$ & $162 \%$ & $164 \%$ \\
Province & & & & & \\
Camarines Sur & $1,861,010$ & $2,062,469$ & $2,411,126$ & $2,944,552$ & $3,083,284$ \\
Increase in the tourist arrival & $100 \%$ & $111 \%$ & $130 \%$ & $158 \%$ & $166 \%$ \\
\hline
\end{tabular}

Source: https://psa.gov.ph/.

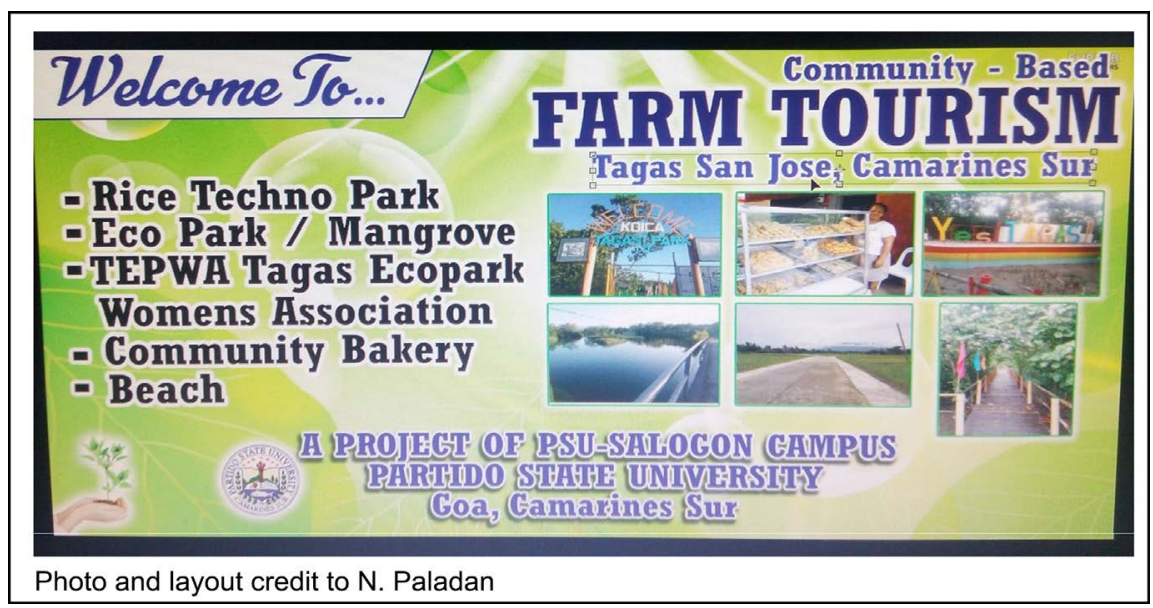

Figure 1. Promotional material for community-based farm tourism in Tagas.

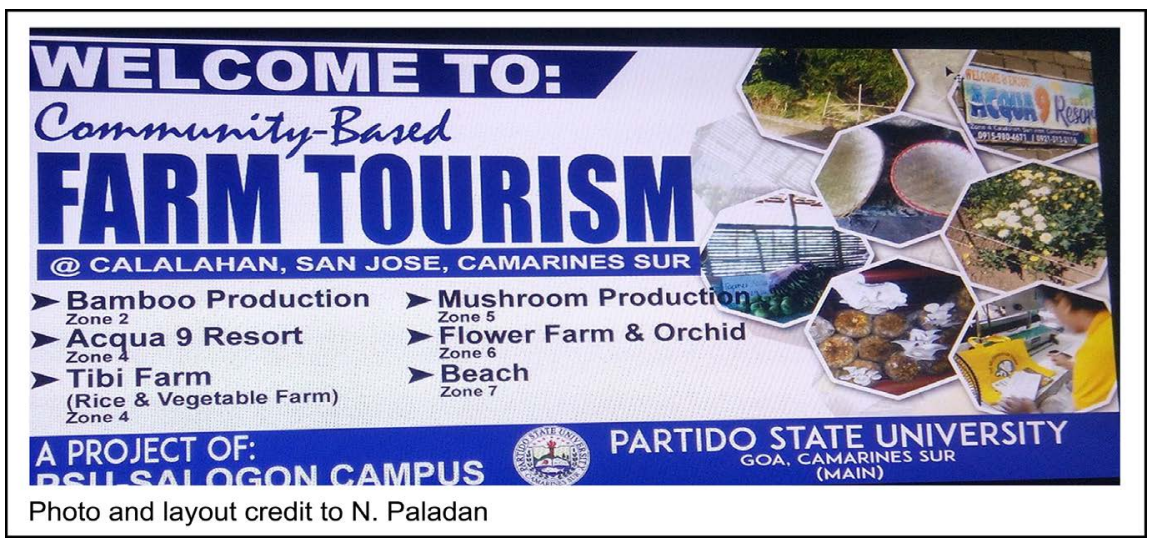

Figure 2. Promotional material for community-based farm tourism in Calalahan. 


\subsection{Lesson Learned in Establishing Farm Tourism Using Community-Based Approach}

Establishing community-based farm tourism was a challenging and there are several lessons that can be learned from this endeavor. First, working with community for this project is a process and it will take time to progress. So getting their cooperation and informing them about the process is really essential. Second, in community-based farm tourism it needs wide community participation and contribution, development in the realization of the project. It was noticed that the support of the local government unit is also crucial. Third, community are now looking for innovative projects that could help them to grow us a community and provide them additional experience, knowledge, skills and livelihood. However, their reception and cooperation are affected by their previous experience in joining a community project. In addition, at the start they are hesitant to partake and they are also impatience of immediate results. And this is similar to the study of Sebele (2010) [29] which state that some members of the community think that their participation in community-based tourism do not compensate the benefits. Lastly, it is essential that the process adopted recognizes the need to prepare the community before they embrace tourism.

\section{Conclusions}

In establishing community-based farm tourism, there are preliminary actions that were taken into consideration such as coordination with the barangay local government unit (BLGU), getting their support and commitment for the project and forming community for the farm tourism project. And to start and develop a community-based farm tourism it adopted the four steps introduce by Vikneswaran Nair and Amran Hamzah (2015) [26], it includes assess community needs and readiness for tourism, educates and prepares the community for tourism, identify and establish leadership team/local champion, and plan and design quality products. This study showed that there are necessary steps to be taken to start a CBT project; however a different approach is needed to sustain the project. Therefore, establishing farm tourism through community-based approach is a process; it needs a support system; and takes time to thrive.

Likewise, the study indicated the benefits and challenges in developing community-based farm tourism. The benefits include sustain the local community in creating income, expanding the local economy, protect the culture, safeguard the environment, and providing educational opportunities. The main challenge of community-based tourism is the local community's attitude towards participation for the project. Hence, for community-based tourism to be effective it requires extensive community participation and involvement in assessment, planning and as well as in the implementation.

Furthermore, there is a growing tourism industry in the Philippines and in the area where this project was conducted. Hence, community-based farm tourism can be integrated in the tourism packages offer to the tourist. Finally, like any 
tourism product, CBT projects need careful planning and management. Projects should not be taken for granted, but require innovation, targeted marketing and regular monitoring to ensure success. Above all, the most successful CBT initiative should be viewed as a means to an end, that is, as a catalyst to nurture thriving rural entrepreneurship in all economic sectors.

\section{Limitation of the Study}

Establishing farm tourism through community-based approach is a process that needs to consider the needs of the communities; the support system from the local barangay unit, the municipal, tourism office, community organizer and also the faculty of higher education institution who conduct extension services; and it takes time to thrive. Since this research project was limited for one year only it is recommended to have a longer period or at least have two phases: one for starting and developing and another phase is the sustainability of the community-based farm tourism. In this study, it only reaches the first phase.

In developing community-based farm tourism, it is recommended to start with the organization and leadership of the local communities who will manage the community-based farm tourism. To be effective it requires extensive community involvement and participation in evaluation, planning and as well as in the implementation of the project.

A long-term approach is needed for a project like developing and establishing community-based farm tourism and must focus on the advantage of the benefits for the local community and not dwell on its challenges. Once the project of community-based farm tourism matures, the implementation of a holistic business model is essential in weaning the project from government or donor reliance, as well as to scale up the project.

\section{Conflicts of Interest}

The author declares no conflicts of interest regarding the publication of this paper.

\section{References}

[1] Colliver, A., Calder, M., Ryan, L., White, C. and Fien, J. (2010) Teaching and Learning for a Sustainable Future-Module 15: Sustainable Agriculture. United Nations Educational, Scientific and Cultural Organization-World Heritage Centre, Paris.

[2] Brandth, B. and Haugen, M.S. (2010) Doing Farm Tourism: The Intertwining Practices of Gender and Work. Signs. Journal of Women in Culture and Society, 35, 425-446. https://doi.org/10.1086/605480

[3] Barbieri, C. (2009) A Comparison of Agritourism and Other Farm Entrepreneurs: Implications for Future Tourism and Sociological Research On Agritourism içinden. Proceedings of the 2008 Northeastern Recreation Research Symposium, Bolton Landing, 30 March-1 April 2008, 343-349.

[4] Canoves, G., Villarino, M., Priestly, G.K. and Blanco, A. (2004) Rural Tourism in 
Spain: An Analysis of Recent Evolution. Geoforum, 35, 755-769. https://doi.org/10.1016/j.geoforum.2004.03.005

[5] Hall, M. and Rusher, K. (2004) Risky Lifestyles? Entrepreneurial Characteristics of the New Zealand Bed and Breakfast Sector. In: Thomas, R., Ed., Small Firms in Tourism: International Perspective, Elsevier, Oxford, 83-97. https://doi.org/10.1016/B978-0-08-044132-0.50009-5

[6] Barbieri, C. (2010) An Importance-Performance Analysis of the Motivations behind Agritourism and Other Farm Enterprise Developments in Canada. Journal of Rural and Community Development, 5, 1-20.

[7] Ollenburg, C. and Buckley, R. (2007) Stated Economic and Social Motivations of Farm Tourism Operators. Journal of Travel Research, 45, 444-452. https://doi.org/10.1177/0047287507299574

[8] Tew, C. and Barbieri, C. (2012) The Perceived Benefits of Agritourism: The Provider's Perspective. Tourism Management, 33, 215-224. https://doi.org/10.1016/j.tourman.2011.02.005

[9] Nickerson, N., Black, R. and McCool, S. (2001) Agritourism: Motivations behind Farm/Ranch Business Diversification. Journal of Travel Research, 40, 19-26. https://doi.org/10.1177/004728750104000104

[10] Barbieri, C. and Mahoney, E. (2009) Why Is Diversification an Attractive Farm Adjustment Strategy? Insights from Texas Farmers and Ranchers. Journal of Rural Studies, 25, 58-66. https://doi.org/10.1016/j.jrurstud.2008.06.001

[11] Mastronardi, L., Giaccio, V., Giannelli, A. and Scardera, A. (2015) Is Agritourism Eco-Friendly? A Comparison between Agritourisms and Other Farms in Italy Using Farm Accountancy Data Network Dataset. SpringerPlus, 4, Article No. 590. https://doi.org/10.1186/s40064-015-1353-4

[12] Goodwin, H. and Santilli, R. (2009) Community-Based Tourism: A Success? ICRT Occasional Paper, 11, 1-37.

[13] Reid, D. (2003) Tourism, Globalisation and Development: Responsible Tourism Planning. Pluto Press. London.

[14] Kiss, A. (2004) Is Community-Based Ecotourism a Good Use of Biodiversity Conservation Funds? Trends in Ecology \& Evolution, 19, 232-237.

https://doi.org/10.1016/j.tree.2004.03.010

[15] Asia-Pacific Economic Cooperation (2014) 2000 APEC Tourism Ministerial Meeting: Seoul Declaration on an APEC Tourism Charter.

[16] Ashley, C. and Garland, E. (1994) Promoting Community-Based Tourism Development: Why, What and How. In: Directorate of Environmental Affairs, Ministry of Environment and Tourism Research Discussion Paper, No. 4, Directorate of Environmental Affairs, Windhoek, 3.

[17] Jamal, T.B. and Getz, D. (1995) Collaboration Theory and Community Tourism Planning. Annals of Tourism Research, 22, 186-204. https://doi.org/10.1016/0160-7383(94)00067-3

[18] Mitchell, R.E. and Reid, D.G. (2001) Community Integration. Annals of Tourism Research, 28, 113-139. https://doi.org/10.1016/S0160-7383(00)00013-X

[19] Reed, M. (1997) Power Relations and Community Based Tourism Planning. Annals of Tourism Research, 24, 566-591. https://doi.org/10.1016/S0160-7383(97)00023-6

[20] Alsos, G.A., Ljunggren, E. and Pettersen, L.T. (2003) Farm-Based Entrepreneurs: What Triggers the Start-Up of New Business Activities? Journal of Small Business and Enterprise Development, 10, 435-443. 
https://doi.org/10.1108/14626000310504747

[21] Tosun, C. (2000) Limits to Community Participation in the Tourism Development Process in Developing Countries. Tourism Management, 21, 613-633. https://doi.org/10.1016/S0261-5177(00)00009-1

[22] Rosenow, J. and Pulsipher, G.L. (1979) Tourism, the Good, the Bad, and the Ugly. Century Three Press, Lincoln.

[23] Healey, J.F. (2009) Statistics: A Tool for Social Science Research. In: Caldeira, C. and Beliso, C., Eds., Michele Sordi, 8th Edition, Michele Sordi, USA.

[24] Vaske, J.J. (2008) Survey, Research and Analysis: Applications in Parks, Recreation and Human Dimensions. Venture Publishing, State College.

[25] Daly, J., Willis, K., Small, R., Green, J., Welch, N., Kealy, M. and Hughes, E. (2007) A Hierarchy of Evidence for Assessing Qualitative Health Research. Journal of Clinical Epidemiology, 60, 43-49. https://doi.org/10.1016/j.jclinepi.2006.03.014

[26] Nair, V. and Hamzah, A. (2015) Successful Community-Based Tourism Approaches for Rural Destinations: The Asia Pacific Experience. Worldwide Hospitality and Tourism Themes, 7, 429-439. https://doi.org/10.1108/WHATT-06-2015-0023

[27] Ahmad, N.A.A. and Nur, A.A.M.S. (2017) Community Based Tourism: Understanding, Benefits and Challenges. Journal of Tourism Hospitality, 6, 1.

https://doi.org/10.4172/2167-0269.1000263

[28] Asia-Pacific Economic Cooperation (2000) Towards Knowledge-Based Economies in APEC, Economic Committee. Asia-Pacific Economic Cooperation Secretariat, Singapore.

[29] Sebele, L.S. (2010) Community-Based Tourism Ventures, Benefits and Challenges: Khama Rhino Sanctuary Trust, Central District, Botswana. Tourism Management, 31, 136-146. https://doi.org/10.1016/j.tourman.2009.01.005 